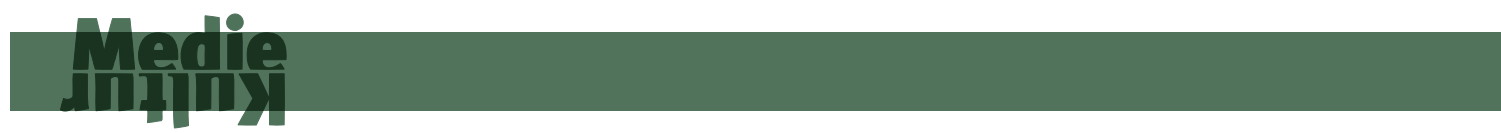

MedieKultur | Journal of media and communication research | ISSN 1901-9726

Book Review

\title{
Roel Puijk (Ed.): Fjernsyn i digitale omgivelser. Kristiansand: IJ-forlaget. 2008
}

\author{
Jannick Kirk Sørensen
}

MedieKultur 2010, 48, 156-158

Published by SMID | Society of Media researchers In Denmark | www.smid.dk The online version of this text can be found open access at www.mediekultur.dk

Begrebet fjernsyn har mistet noget af sin selvfølgelighed med de interaktive mediers fremkomst. Bogen Fjernsyn i digitale omgivelser beskæftiger sig primært med hvordan dette selvfølgelighedstab udfolder sig i Norge. Bogen indeholder også oversatte artikler, nemlig en revideret version af William Uricchios "Old Media as New Media, Television" (2002) og Georgina Borns “Digitalising Democracy” (2005). Hovedsageligt omhandler bogen dog norske mediers møde med og reaktion på digitaliseringens forskellige konsekvenser. En del af disse er formentlig den velorienterede læser bekendt, f.eks. øget brugerinddragelse og "flermedial produksjon" som bogen kalder det. Globaliseringen sætter også sine spor i bogen: de norske versioner af internationale tv-formater diskuteres, ligesom der i øvrigt også sammenlignes internationalt. Primært har bogen dog sit fokus på den norsksprogede medieoffentlighed.

Roel Puijks artikel “Fjernsyn i endring” er en oversigtsartikel, der på en gang introducerer bogens kapitler og forklarer digitaliseringens virkninger og konsekvenser. Oversigtsartikler berører i sagens natur kun de enkelte emner let, men Puijks artikel kommer desværre også til at blive en noget overordnet altomfattende oversigt. Det er lidt uklart hvem bogens målgruppe er; en ikke-medievidenskabelig læser ville måske have haft brug for en anden type oversigtsartikel, en artikel mere på formidlingens præmisser end på medieforskningens. Omvendt udgør bogens bidrag til medieforskning hovedsagelig en undersøgelse af generelle forhold i en specifik norsk kontekst.

Yngvar Kjus' artikel "Kampen om oppmerksomheten” viser gennem indgående pro- 
duktionsstudier hvordan henholdsvis NRK og norsk TV2 lærer at optimere eksponeringen af bestemte programformater (NRK's "Store Norske" og TV2's "Idol") på tværs af medier. NRK's faseopdelte eksponering efterlader internettet som et appendiks, der aldrig får sit eget liv, mens "Idol"s faste tilbagevendende rytme giver et godt cyklisk samspil mellem tv-udsendelsen, radio og internet. To mindre cases analyseres også: NRK's forsøg med cross-mediale enkeltevents. De forskellige mediers forskellige produktionsrytmer og produktionsomkostninger fører til kampe om ressourcer, prestige og om at være først med offentliggørelsen. Især for fjernsynet har medieindhold en vigtig ferskvare-funktion i den strategiske profilering af de forskellige medietyper.

Brit Svoens "Fra skolefjernsyn til nettbaseret læringsressurs" viser hvordan skiftet til digital produktion ikke udvider den pædagogiske frihed, men i stedet virker indsnævrende. Kravet til genanvendelighed og modulérbarhed kræver en formalisering og standardisering af programindholdet, der egentlig virker passiviserende i stedet for aktiverende: E-læring som "porsjonspakker med lang holdbarhetsdato" (p. 120). Svoen sammenligner tre læringsressourcer: NRK's "Puggandplay”, Disneys "Cosmeo" og den Los Angeles-baserede uddannelses-tv-station KLCS og deres "Homework Hotline". De tre læringsressourcer har ganske forskellige baggrunde og er også valgt netop på grund af deres forskelligheder, og fordi de alligevel arbejder med den præcis samme målgruppe (lektiehjælp til børn) og alle er mødt af digitaliseringens udfordringer, inklusive paradokserne i brugerinddragelse.

Kari Aakerli Vik kigger også på den historiske udvikling i medieret formidling, men her på hvordan kunst formidles i NRK. Vik analyserer i "Fra "professorstyrt" folkeoplysning til "journaliststyrt" opplevelsesfjernsyn?" fire faser af NRK's kunstformidling: 1960'erne, perioden 1974-85, 1994 og 2001-2006. Et gennemgående træk i udviklingen, som kendes fra stort set al behandling af kunst i tv, er en bevægelse fra at fortælle om kunsten, over forsøg på at formidle kunsten gennem fjernsynsmediet, til den nuværende brug af kunsten som katalysator for tv's egen diskussion. Artiklen har ikke nogen større diskussion af digitalisering eller interaktivitet; på sin vis passer artiklen ikke i bogen. Alligevel giver den et ganske præcist billede af hvordan fjernsynsmediet historisk set, da det var blevet sine egne virkemidler og magt bevidst, underordnede alle andre medieformer sine vilkår og interesser. Nu synes denne magtposition langsomt at være ved at vakle.

Roel Puijks "Faktajournalistikk og den aktive seer" beskæftiger sig med forholdet mellem tv og internet i forhold til journalisternes konstruktion og inddragelse af publikum. Kapitlet er en detaljerig gennemgang af hvordan NRK's helsestof over en årrække er blevet differentieret ud på de forskellige medier, og hvordan NRK-journalisterne gradvist har lært at optimere de forskellige mediers kommunikative egenskaber i forhold til stofområdet, især i forhold til publiceringsrytme. Kapitlet diskuterer også andre spørgsmål såsom helseeksperters autoritet, brugen af reality-tv og inddragelse af publikum. Den store detaljerigdom som Puijks omfattende empiriske materiale har samt de mange temaer bevirker imidlertid at kapitlet føles en smule langt.

"Fjernsyn og nærvær" af Claus Knudsen, Sigmund Andresen og Roel Puijk adskiller sig fra 
bogens øvrige bidrag ved at skildre og vurdere et teknologisk-kommunikativt eksperiment. Videokonferencesystemer hvor deltagerne gensidigt kan se hinanden finder ikke p.t. anvendelse i almindelig tv-produktion. Når studieværten interviewer en reporter eller en medvirkende, der befinder sig "i marken", kan den interviewede ikke se intervieweren. Ved hjælp af en teknisk forsøgsopstilling med et teleprompter-lignende apparat og en række forskellige kommunikative situationer med adskilte samtalepartnere undersøger projektet om følelsen af nærvær er højere, når begge samtalepartnere kan se hinanden i øjnene. Dels undersøges deltagernes oplevelse, dels et til lejligheden sammenbragt publikums. Eksperimentet er spændende fordi det, med udgangspunkt i de allertidligste forestillinger om television fra 1877 (jf. Uricchios bidrag, p. 57) som et tovejsmedie analogt med telefonen, søger nye udviklingsveje for broadcast live-tv. Målet er dog større: nemlig at bidrage til forskningen i "tele-presence". Kapitlet virker, trods sit lidt mere tekniske tilsnit, forfriskende fremadskuende og perspektivrigt blandt de andre bidrag.

Bogen kan sine steder virke bagudskuende i stedet for fremadskuende. Den fokuserer ofte på det forsvundne, men bag diskussionen af ændrede mediedistributionsformer gemmer der sig en mediepolitisk diskussion som bogen desværre ikke tager op. Det vil, efter min mening, være forkert at gøre spørgsmålet om public service-mediets forandring til en funktion af teknologisk forandring. Den teknologiske udvikling sætter visse rammer for ændringerne, men den sker ikke uden en mediepolitisk diskussion. Man kan derfor i flere af casestudierne savne en mediepolitisk perspektivering som supplement til iagttagelserne af, hvordan nye medier udfordrer gamle produktions- og organisationsformer.

Jannick Kirk Sørensen

Ph.D.-stipendiat Institut for Litteratur, Kultur og Medier Syddansk Universitet, Danmark jannicks@litcul.sdu.dk 